\title{
Improving Tourism Competitiveness: The Case of Mexico
}

\author{
Marco Serrato \\ Department of Industrial Engineering. Tecnológico de Monterrey, campus Toluca \\ E. Monroy Cárdenas 2000. Toluca, México. 50110. \\ Tel: 52-722-279-9990Ｅ-mail: mserrato@itesm.mx
}

Karla Valenzuela

Department of Industrial Engineering. Tecnológico de Monterrey, campus Toluca

E. Monroy Cárdenas 2000. Toluca, México. 50110.

Tel: 52-722-279-9990Ｅ-mail: kvalenzuela@itesm.mx

Victor Rayas (Corresponding author)

Department of Industrial Engineering. Tecnológico de Monterrey, campus Toluca

E. Monroy Cárdenas 2000. Toluca, México. 50110.

Tel: 52-722-279-9990Ｅ-mail: victor.rayas@invitados.itesm.mx

Received: October 27, 2012 Accepted: November 10, 2012

doi:10.5296/ber.v3i1.2574 URL: http://dx.doi.org/10.5296/ber.v3i1.2574

\begin{abstract}
Through this research, a categorization and analysis of resources and actions taken by each Mexican state that contribute towards tourism competitiveness is developed. Such competitiveness is evaluated through one hundred and twelve variables, which are grouped in ten categories defined as dimensions. An overall competitiveness index is developed for each state, as well as complementary indexes for each state under the ten dimensions considered. The results of the research are satisfactory, since governmental authorities reported improvements on the number of tourists and the average expenditure. Such results were
\end{abstract}


achieved by developing new initiatives and projects defined by identifying the strengths and opportunity areas in each state regarding tourism competitiveness, which are outlined through this research.

Keywords: Competitiveness, Decision-Support Systems, Mexico.

\section{Introduction}

Tourism is one of the largest generators of wealth and employment in the world (Enright \& Newton, 2004). The tourism industry constitutes $11 \%$ of global Gross Domestic Product, supports two hundred million jobs worldwide and $8 \%$ of total employment. In the last three years, some 8.5 million jobs have been created as a result of growth in tourism. Even more, tourism is expected to continue to grow more rapidly than the world's economic output (Taleghani, 2010), because of factors such as population growth, rising incomes and employment, shorter working weeks in many parts of the world, and the increasing integration of the world's economies and societies. Because of these reasons, a tremendous growth of tourism as a field of study, coupled with increasing demand for tourism education, has led to a heightened focus on research and publications related to this economic sector (Barros, 2005; Jogaratnam, Chon, McCleary, Mena \& Yoo, 2005; Reid \& Bojanic, 2005). Based on these facts and analyses, tourism can be positioned as a mechanism for promoting economic growth and development (Matarrita-Cascante, 2010; Meyer, 2002). As an economic growth strategy, tourism is sought for generation of foreign exchange, increased employment, attraction of foreign capital, and promotion of economic independence (Ren, et al., 2010). In the context of developing countries, the most important economic feature of activities related to the tourism sector is that they contribute to three high-priority goals: the generation of income, employment, and foreign-exchange earnings (Taleghani, 2010).

In the particular case of Mexico, tourism is one of the economy sectors with the largest capacity to generate benefits and positive effects on the social, economic and environmental spheres (INEGI, 2010). As stated by the World Travel and Tourism Council (2010), the contribution of the travel and tourism industry to Mexico's Gross Domestic Product is expected to rise from $12.7 \%$ (US\$121.5bn or MXN\$1,601.4bn) in 2010, to $14.2 \%$ (US\$243.2bn or MXN\$3,649.0bn) by 2020. Even more, the number of jobs is expected to rise from $5,881,000$ in 2010 (13.7\% of total employment or one in every 7.3 jobs) to $7,105,000$ jobs ( $14.7 \%$ of total employment or one in every 6.8 jobs) by 2020 . Because of the reasons mentioned above, the development of new initiatives and projects to promote tourism competitiveness among the different states of Mexico has been defined as a priority topic at the nationwide level (Carral, 2007; Ibáñez \& García, 2009; Propin \& Sánchez, 2010; Viktorovna, 2010). Through this research, an initiative to promote tourism competitiveness among the states of Mexico is developed. Such initiative is achieved through a categorization and analysis of resources and actions taken by each Mexican state that contribute towards tourism competitiveness. One hundred and twelve variables is selected and grouped into ten categories, defined as dimensions, by a group of experts consulted by the researchers in charge of this project. The variables selected describe: 1) the existence of resources and 
infrastructure that is relevant to the tourism activity in its different branches; 2) the actions taken at each Mexican state to consolidate this sector; and 3) the results obtained in this vein. Based on this set of variables and the ten dimensions under which they are grouped, an overall competitiveness index (Raya, 2004) is developed for each state, as well as an index for each state under these ten dimensions. A detailed analysis of the current status for each of the Mexican states is also outlined, by identifying the strengths, opportunity areas and priority projects to be developed in each of such states.

The variables considered on the research are selected through an exhaustive analysis of relevant factors (Subhash, 2002; Verdiell, Sabatini, Maciel, \& Rodriguez, 2005) that contribute towards tourism competitiveness of a country, region and state. This allows researchers and stakeholders involved in this initiative to identify the most important elements related to tourism competitiveness; but also to identify, prioritize and develop new initiatives and projects, which involve the active participation of governmental, private and academic organizations. The final goal is to identify the comparative and competitive position of each Mexican state regarding tourism competitiveness, but also to contribute to its development in a sustainable manner by supporting the decision-making process at each state. Such decision-making process involves different factors such as: protection of natural areas and cultural heritage sites, human resource development, development of hotel infrastructure and related services, tourism promotion, development of complementary services, attraction of tourism-related foreign investment, etc. This document is structured as follows: an introductory analysis of tourism competitiveness is stated on section 2; while the methodology, objectives and stages considered throughout the research are shown on section 3. In the same vein, the projects developed based on the results obtained are outlined on section 4 , while the conclusions are stated on section 5. Finally, the main opportunities for further research are described on section 6 .

\section{Tourism Competitiveness}

In recent years, the concept of competitiveness has emerged as a new paradigm in sustainable economic and social development (WEF, 2010). As described by Begg (1999), depends on the ability to sustain change in the factors that give rise to productivity growth (technology, human resources, etc.), but also the structure of the economy and how policy seeks shape it (Rita, 2000). Competitiveness is not a 'zero sum game' (Racherla \& Hu, 2010). In other words, an increase of this factor in one country, region or state, does not come at the expense of another (Crouch \& Brent, 1999). On the contrary, gains in productivity and efficiency in different countries, regions or states, can and must be integrated and mutually reinforcing. Destination competitiveness has tremendous ramifications for the tourism industry, and is therefore of considerable interest to practitioners and policy-makers (WTO, 2006). Dwyer, Forsyth \& Rao (2000) support this view stating that it is useful for the industry and governmental sectors to understand where a destination's competitive position is weakest and strongest. This is of special importance in countries like Mexico, where the tourism industry represents a key wing in its economy. As it happens in all countries, the states of Mexico are not homogeneous, since they present significant differences in the presence of tourism attractions, natural resources, cultural heritage sites, tourism infrastructure, human resources, 
and on initiatives developed to support such activities. In the same vein, economic and social development in these states has been determined by different factors throughout the years, which is why it is crucial to measure the current status of each state in terms of tourism competitiveness, as well as the role that tourism should play as an engine for economic and social development in each state. It is important to be able to measure and compare the tourism competitive status of each state, such that projects and initiatives can be developed according to the strengths and opportunities identified, as well as according to the particular vision defined on each state for the role that tourism should play on its economic and social development.

Internationally recognized organizations like the World Economic Forum (WEF, 2010) and the Institute for Management Development (IMD, 2010) have developed valuable studies to analyze and compare competitiveness among countries. Such studies capture the main factors that influence it, through a combination of the current status of each one of them. These studies also consider geographical areas that include several countries, in order to develop analyses on a regional basis. In the same vein, particular studies have been developed for the states of Mexico, such as the study named "The Competitiveness of the Mexican States" (Campos, et al., 2007), developed by the Graduate School of Public Administration of Tec de Monterrey, as well as the study developed by the Mexican Institute for the Competitiveness (IMCO, 2010). These documents represent useful methodologies to measure competitiveness in the states of Mexico, which include several factors and variables in its analysis: economic development, governmental efficiency, business efficiency, infrastructure, legal system, environmental sustainability, international trade, etc. However, there is no particular analysis to support the decision-making process regarding tourism competitiveness, since these studies consider it on a more general and broader (and very useful) basis, but without a specific scope on supporting the decision-making process of local organizations (public and private) at a state level) involved in tourism competitiveness.

In the particular case of tourism competitiveness, the World Tourism Organization (WTO, 2006), as well as the WEF (2010), have also developed interesting and useful studies on a country or regional basis. Criteria like business environment, infrastructure, human resources, cultural heritage, natural resources, among others, are considered in these studies. However, they are not specifically focused on providing a decision support system for stakeholders and organizations involved in local activities in this sector, but provide valuable insights on a nationwide level. Based on the previous analysis, it can be identified that the main contribution of this research is obtained through a categorization and analysis of resources and actions taken by each Mexican state that support tourism competitiveness. As previously explained, this is evaluated through one hundred and twelve variables, which are grouped into ten dimensions. These variables describe the existence of resources and infrastructure that is relevant for the tourism activity in its different branches, as well as the actions taken at each Mexican state to consolidate this sector. The main objective is to generate valuable data and information that allows decision-makers at a state-level in Mexico, to identify the priorities required to consolidate tourism as an engine for economic and social development in their states. As explained in Section 3, a detailed analysis is outlined for each state, 
identifying strengths, opportunity areas and priority projects to be developed in each of the thirty-two states of Mexico.

\section{Development of the ICTEM Index and Its Corresponding Analysis}

The development of the tourism competitiveness index for the states of Mexico (ICTEM), as well as the corresponding analysis, managerial insights and conclusions identified through it, were achieved through the next five stages: objectives of the study, dimensions considered in the study, variables considered for each dimension, development of the ICTEM index and detailed data for each state under each dimension and results obtained and managerial insights. Throughout this section, the activities, research and parties involved on each stage are explained in detail.

\subsection{Stage 1 - Objectives of the Study}

To define the objectives of the study, a group of forty-five people was selected and invited to participate in a series of sessions where the Delphi technique (Norese \& Toso, 2004; Whitman, 1990) was applied. Such people belonged to public, private and academic organizations related to tourism activities at the local, regional and national level in Mexico. The conformation of this group was validated by specialized staff at the Ministry of Tourism of Mexico, whom provided valuable expertise in this manner. At the end, thirty-six out of forty-five experts participated actively, including representatives from the three sectors mentioned above. The main objectives defined for the research project are summarized as follows:

- Develop an overall tourism competitiveness index for each of the states of Mexico. Such overall index will state a comparative position for each state, among the rest of them. To create the overall tourism competitiveness index that would allow the analysis and comparisons among states, a set of variables was selected and grouped under particular criteria. To assure comparability, a cardinal analysis was considered. Such comparability was performed among states. As a complement, quartiles containing eight states each and adding up to the thirty two states of Mexico were also identified.

- Define ten criteria - labeled as "dimensions" - through which tourism competitiveness in the states of Mexico can be measured. Each dimension will contain a set of variables through which such dimension can be clearly defined and measured. The competitiveness index for each state under each dimension will be identified as well, in order to compare them and identify strengths and opportunities among states for each dimension.Ten dimensions were defined by the group of experts. Each dimension was created by selecting, grouping and analyzing a set of variables that would describe accurately the competitive position for each state under such dimension. Quartiles to group the states on each dimension were created as well. The selection and grouping of the variables considered to define such dimensions was also performed by the group of experts. At the end, one hundred and twelve variables were considered and grouped under the ten dimensions defined. The information related to 


\section{$\Lambda$ Macrothink}

Business and Economic Research ISSN 2162-4860 2013, Vol. 3, No. 1

each of these variables came from reliable sources accepted and used by the experts consulted, and also validated by the group of researchers in charge of this initiative.

- Identify the leading states in terms of tourism competitiveness, under each of the dimensions defined and considered. Based on the results obtained by achieving objective 2, the top five states, under each of the ten dimensions considered were identified as well. Even more, common characteristics among each group of five leading states were also defined, in order to describe the main variables that contribute towards greater competitiveness under each dimension.

- Group and describe in detail the characteristics, strengths and opportunities of each state that contribute towards its tourism competitiveness index. Such analysis included, as a start, descriptive data like the number of counties in each state, total population, average educational level, main economic activities, state's contribution to the national Gross Domestic Product (as a percentage), among others. An analysis for the state under such overall tourism competitiveness, as well as under each of the dimensions considered, was also included. Based on this analysis, the main strengths and opportunity areas for the development of tourism competitiveness in each state were also identified.

- Identify the comparative position for each state, under each of the variables considered on all dimensions, and develop a Markov-Decision Model (MDM) to support stakeholders and decision-makers involved on tourism competitiveness on a state basis. As a final step of the study, a detailed analysis was performed, in order to identify the comparative position for each of the thirty two states, under each of the one hundred and twelve variables considered. Through this analysis, the comparative situation for each state under each of the variables included in the research would be identified.

\subsection{Stage 2 - Dimensions Considered on the Study}

To develop the ICTEM index, a set of dimensions were defined. Such dimensions are summarized in Appendix 1, and correspond not only to resources, but also actions and results obtained in each state, towards tourism competitiveness. These dimensions consider all of the elements that, under the criteria of the group of experts and researchers involved, influence the development of tourism as an engine for economic and social development in each state. As described before, these dimensions are composed of a set of variables that, together, define such dimension.

\subsection{Stage 3 - Variables Included on the Research for Each Dimension}

Table 1 shows the dimensions and variables considered for the research project. As previously stated, one hundred and twelve variables were finally included, which are grouped in the ten dimensions defined in the study. To come up with the final set of variables selected, an initial group of three hundred twenty two variables were initially considered by the experts participating in this process. These variables were ranked and discriminated until one hundred and twelve were finally included in the analysis, which represent the main factors used to define and measure the competitive and comparative position of each state under 
these dimensions.

\subsection{Stage 4 - Development of the ICTEM index}

The ICTEM index was defined as a weighted average of the ten dimensions considered throughout the study, as follows:

$$
I_{C T E M_{k}}=\alpha_{1} C H_{k}+\alpha_{2} N R_{k}+\alpha_{3} H I_{k}+\alpha_{4} C I_{k}+\alpha_{5} C S_{k}+\alpha_{6} P S_{k}+\alpha_{7} T P_{k}+\alpha_{8} G P_{k}+\alpha_{9} E E_{k}+\alpha_{10} H R_{k}
$$

Where

$\operatorname{ICTEM}_{k}=$ tourism competitiveness index for state $k$;

$\mathrm{CH}_{k}=$ cultural heritage index for state $k$;

$N R_{k}=$ natural resources index for state $k$;

$H I_{k}=$ hotel infrastructure index for state $k$;

$C I_{k}=$ communications infrastructure index for state $k$;

$C S_{k}=$ complementary services index for state $k$;

$P S_{k}=$ public security index for state $k$;

$T P_{k}=$ tourism promotion index for state $k$;

$G P_{k}=$ governmental participation index for state $k$;

$E E_{k}=$ economic efficiency index for state $k$, and

$H R_{k}=$ human resources index for state $k$.

Parameters $\alpha_{1}, \alpha_{2}, \alpha_{3}, \alpha_{4}, \alpha_{5}, \alpha_{6}, \alpha_{7}, \alpha_{8}, \alpha_{9}, \alpha_{10}$, where $\sum_{i=1}^{10} \alpha_{i}=1$, correspond to the weight assigned to each of the dimensions considered on this study. Such weights were obtained through the main components technique (Doane, 2005; Grigoroudis, Politis, \& Siskos, 2002; Johnson, 2000). In particular, the $\mathrm{CH}_{k}$ index was obtained as a weighted average of three subindexes, defined as follows:

$$
C H_{k}=\beta_{1}^{R C} W+\beta_{2}^{R C} X+\beta_{3}^{R C} Z
$$

where $\beta_{j}^{R C}, j=1,2,3$, and $\sum_{j=1}^{3} \beta_{j}^{R C}=1$, correspond to the weight assigned to each of the

subindexes considered inside the cultural heritage dimension. Such weights were also obtained through the main components method. Each subindex $W, X$ and $Z$ was created as a weighted sum of five variables. Such division in subindexes inside this dimension is made since it allowed a more accurate implementation of the factorial analysis (Gil, 2000; Granizo, 1997) by grouping the number of variables in a better manner, according to the existing states in Mexico. 


\subsection{Stage 5 - Results Obtained and Managerial Insights}

The main results obtained for the index generated under each dimension are:

- Cultural heritage. Leading states: Distrito Federal, México, Oaxaca; state located in the middle of the ranking: Guerrero; state with the lowest index: Durango.

- Natural resources. Leading states: Baja California Sur, Baja California, Sonora; state located in the middle of the ranking: Yucatán; State with the lowest index: Distrito Federal.

- Human resources. Leading states: Distrito Federal, Baja California Sur, Guerrero; state located in the middle of the ranking: Aguascalientes; state with the lowest index: Chiapas.

- Hotel infrastructure. Leading states: Guerrero, Baja California Sur, Distrito Federal; state located in the middle of the ranking: Sinaloa; state with the lowest index: Tlaxcala.

- Communications infrastructure. Leading states: Distrito Federal, Guerrero, Baja California Sur; state located in the middle of the ranking: Sinaloa; state with the lowest index: Durango.

- Complementary services. Leading states: Distrito Federal, Guerrero, Baja California Sur; state located in the middle of the ranking: Campeche; state with the lowest index: Chiapas.

- Public security. Leading states: Colima, Yucatan, Baja California Sur; state located in the middle of the ranking: Guanajuato; state with the lowest index: Distrito Federal.

- Economic efficiency. Leading states: Baja California Sur, Baja California, Coahuila; state located in the middle of the ranking: Oaxaca; state with the lowest index: Tlaxcala.

- Tourism promotion. Leading states: Quintana Roo, Aguascalientes, México; state located in the middle of the ranking: Sonora; state with the lowest index: San Luis Potosí.

- Governmental participation. Leading states: Colima, Distrito Federal, Aguascalientes; state located in the middle of the ranking: Hidalgo; state with the lowest index: Tlaxcala.

The final results obtained for the overall ICTEM index are stated on figure 1, which shows the values obtained for each state and the corresponding ranking. Similar graphs and rankings were obtained for each dimension, which allowed federal and state governments to identify the current status, strengths and opportunity areas not only on its overall tourism competitiveness level, but also on its particular competitiveness level under each of the ten dimensions considered. 


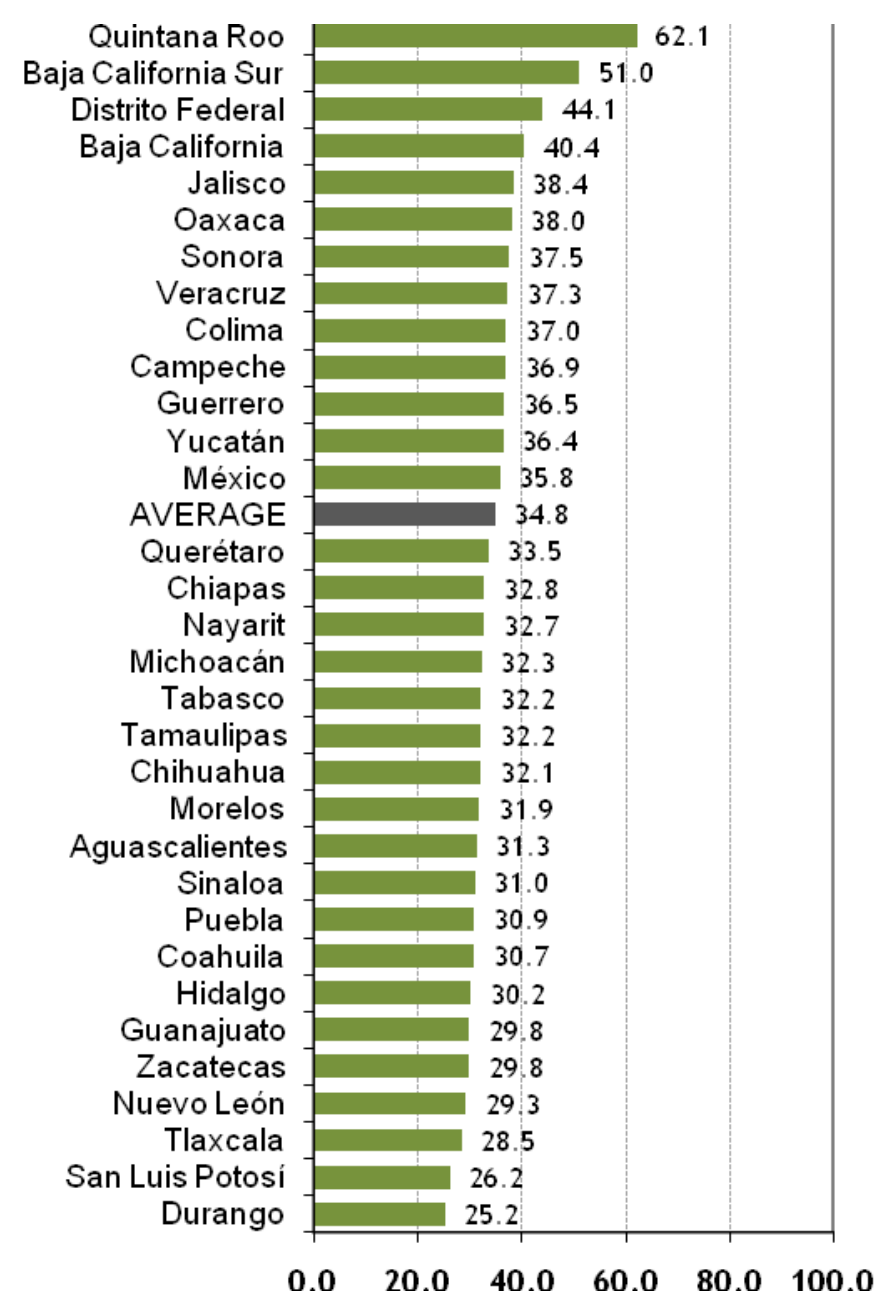

Figure 1. Overall tourism competitiveness index (ICTEM)

In order to identify the geographical distribution of the results obtained, a quartiles map (figure 2) was also developed for the overall ICTEM index. Given that there are thirty two states in Mexico, each quartile contains eight states. This analysis was of special importance for the Ministry of Tourism of Mexico, since it would allow decision-makers to identify the current status in the different tourism regions of Mexico, and define regional projects, budget allocation, tourism promotion campaigns, and infrastructure development initiatives based on such results. 


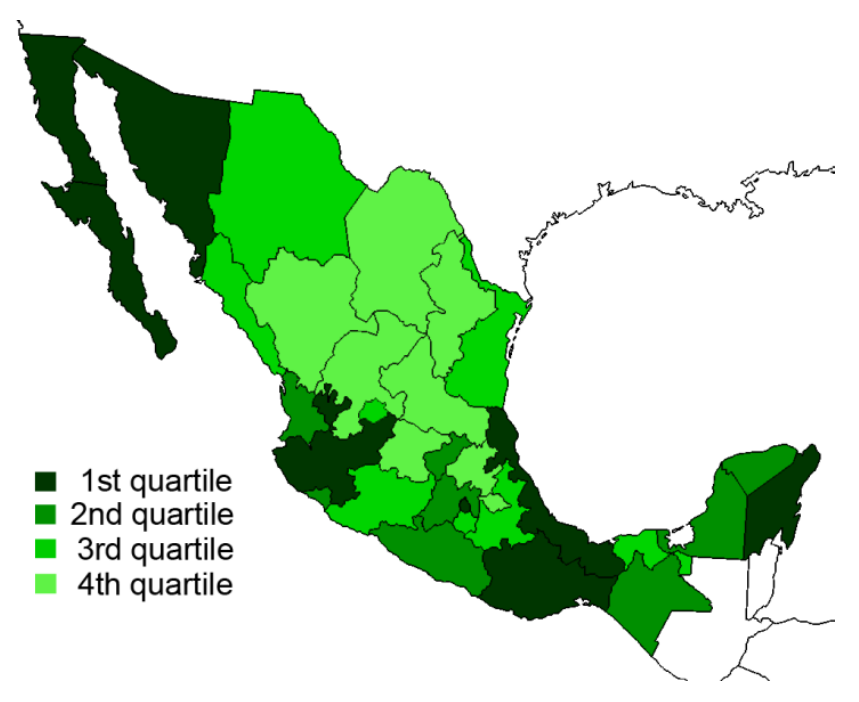

Figure 2. Quartiles map obtained for the ICTEM Index

Similar maps were developed for each dimension. These maps allowed decision-makers at the state and federal level to identify the current status under each dimension on a regional basis, such that specific projects with the joint participation of the federal and the corresponding state governments in these regions could be identified. In a similar manner, a detailed analysis was developed for each of the thirty two states, not only under the overall ICTEM index, but also under the results obtained under each of the ten dimensions. Figure 3 and 4 shows the radar graphs that were created for the State of Quintana Roo and Baja California Sur, respectively. These graphs integrate the results obtained for each state under each of the ten dimensions, and compare such results against: 1) the average result of the top five leading states for each dimension, and 2) against the national average obtained under each dimension.

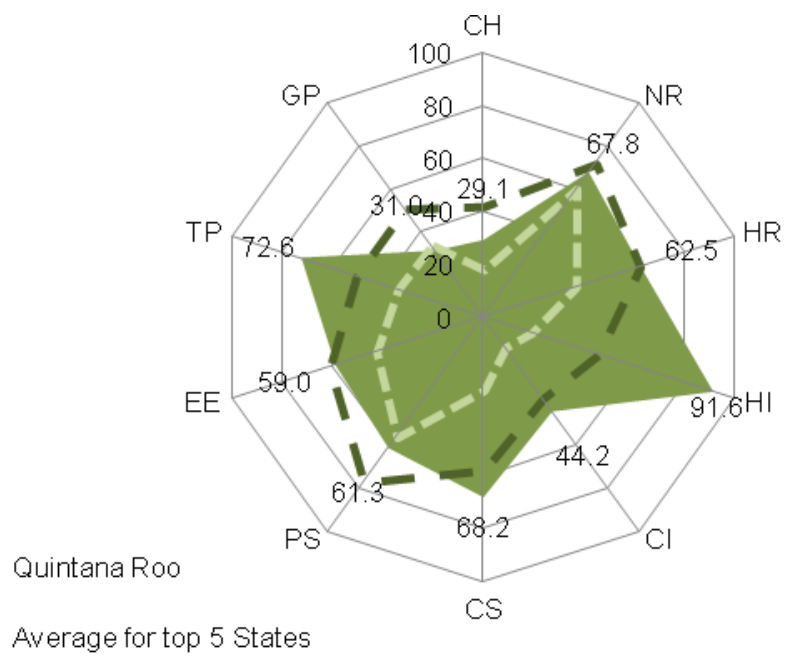

National average

Figure 3. Radar graph for the Mexican State of Quintana Roo 


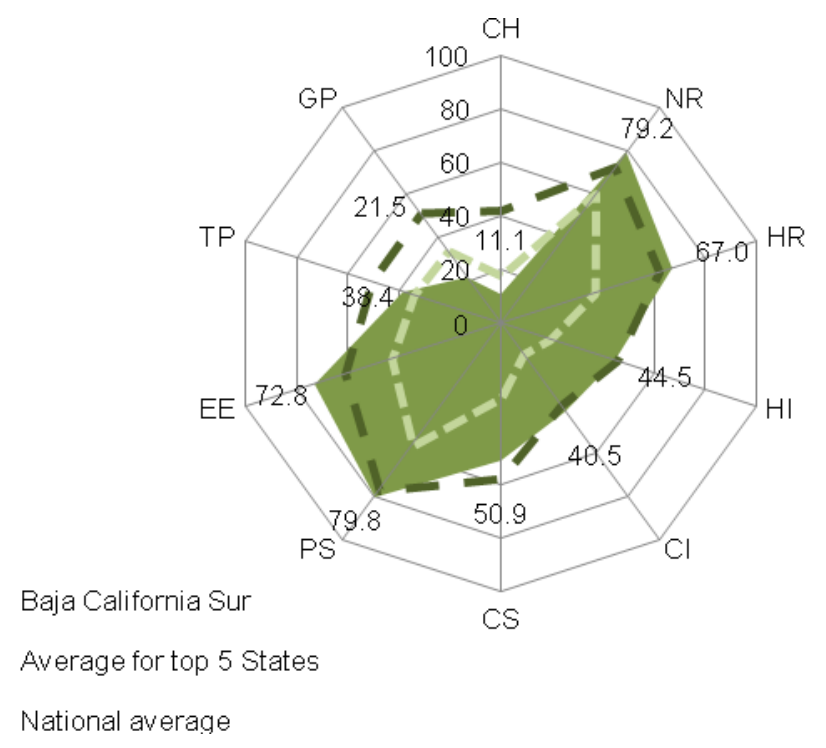

Figure 4. Radar graph for the Mexican state of Baja California Sur

Similar graphs were obtained for the thirty-two states, which were delivered and discussed with representatives of the Ministries of Tourism at the state level, as well as with councils and boards of trustees of key private sectors related to tourism activities (hotel, leisure-focused organizations, restaurant \& food organizations and chains, travel agencies, etc.) with a relevant activity at the state level. These radar graphs provided valuable insights for decision-makers, since they allowed them to identify its comparative position against the leading states and the national average under each dimension. As an illustrative example, it can be identified for the State of Quintana Roo that: 1) it has several strengths in most dimensions, which actually positioned it at the top level on the overall index; and 2) its main opportunities for improvement arise on the fields of 'Governmental Participation', 'Cultural Heritage' and 'Public Security', even though it is positioned above the national average under some of these criteria. Similarly, it can be identified for Baja California Sur that: 1) its main strengths for tourism competitiveness arise on 'Public security', 'Natural resources', 'Economic efficiency' and 'Human resources'; and 2) its main opportunity areas arise on 'Governmental Participation' and 'Cultural Heritage', when compared against the other states. To detail this analysis on a state and regional basis, a set of one-hundred twelve graphs were also developed, which contain the data available for each one of the variables included on the study. These graphs allowed decision-makers to pursue specific actions, projects and initiatives that would seek an improvement on specific challenges on the corresponding dimensions, and that would contribute to improvements on the overall index. The main challenge at this stage was to identify the priority projects and initiatives to develop, that would contribute in a greater proportion to improve tourism competitiveness in a sustainable, but feasible manner, according to the current status at each state. 


\section{Managerial Insights and Projects Developed}

Based on the results obtained from the research project performed, as well as from the analysis of the results generated, a set of initiatives were developed for several states that actively participated on this initiative, as well as regional projects under the coordination of the Ministry of Tourism of Mexico. In Sections 4.1 and 4.2, the main initiatives and projects for the States of Quintana Roo and Baja California Sur are outlined. Similar projects were also generated for other states.

\subsection{Priority Projects for the State of Quintana Roo}

The priority initiatives defined to take advantage of the strengths in the State of Quintana Roo were: 1) maintain availability and diversity of natural areas; 2) keep and, if possible, improve current levels of tourism-oriented working force; 3) maintain current leadership on hotel diversity and availability; 4) maintain the occupancy rate obtained throughout the year; 5) keep the current rate of international tourists; 6) continue improving the current capability for international connections; 7) continue improving the amount and diversity of car rental companies, sport clubs and golf courses available in the state; 8) maintain current leadership on tourism-oriented private and public investment attracted; 9) keep market share and top-of-mind share of its main destinations (Cancun, Riviera Maya, etc.); and 10) maintain investment level on tourism promotion. In the same vein, its main projects defined as a consequence of its opportunity areas were: 1) development of new cultural areas and centers, including museums; 2) improve the governmental efficiency process related to new business-set-up in the state; 3 ) improve the current value on the environmental crime rate; and 4) improve the recovery system and public image towards hurricanes in the peninsula

\subsection{Priority Projects for the State of Baja California Sur}

The priority projects defined to take advantage of the strengths in the State of Baja California Sur were: 1) maintain the amount and diversity of certified natural sites and human-world heritage sites; 2) keep the current average educational level; 4) maintain and improve current hotel availability and diversity; 5) maintain the existing communication infrastructure on a national and international basis; 6) maintain leadership at the nationwide level on insecurity and crime rate state reports; 7) maintain the high confidence-rate of the community towards local government achieved nowadays; 8) maintain and, if possible, improve capability to attract foreign investments. Its main projects defined to improve its opportunity areas were: 1) increase cultural tourism activities for foreign tourist; 2) increase investment on protection and maintenance of natural sites; and 3) improve the number and participation of " $M$ award" consultants in the state.

\subsection{Impact on Economic and Social Development}

The projects developed contributed to an increase on the number of tourists that visited these states, as well as on the average expenditure per tourist, which contributed to an improvement on the total expenditure reported for tourism activities. But above that, they contributed to generate improvements on an economic and social scale in a state and regional basis in Mexico. In the same vein, the project supported the development of public policies, as well as 
particular projects and initiatives, leaded by decision-makers and stakeholders involved on tourism competitiveness in the states considered for the research.

\section{Conclusions}

Tourism can be positioned as a mechanism for promoting economic growth and development. In the particular case of Mexico, tourism is one of the economy sectors with the largest capacity to generate benefits and positive effects on the social, economic and environmental spheres. Through this research, an initiative to promote tourism competitiveness among the states of Mexico was developed. This initiative included a categorization, ranking and analysis of resources and actions taken by each Mexican state, which contribute towards tourism competitiveness. The analysis and results obtained aimed to support the decision-making process at a state level. One hundred and twelve variables were considered in total, which were also grouped into ten dimensions. Particular results and analyses were also performed for the ten dimensions, as well as for each of the thirty-two states in the country. The results obtained were satisfactory, since the projects and initiatives developed by the Ministry of Tourism of Mexico based on the results obtained, as well as by other Ministries of Tourism at a state level, contributed to generate improvements in the number of tourists that visited these states, as well as on tourist's average expenditure. These results were achieved by developing new initiatives and projects focused on improvements on tourism infrastructure, tourism promotion, budget allocation process, human resource development, among others. These initiatives and projects were defined by identifying the strengths and opportunity areas in each state regarding tourism competitiveness, which were outlined through this research. This initiative represented several advantages for decision-makers involved in the development of tourism competitiveness on a state basis in Mexico. However, it is also relevant to mention the limitations of the results obtained. Given that a significant part of the analysis was based on the numerical results obtained for the overall tourism competitiveness index, as well as on the results generated under each dimension, decision-makers have to be careful in further analysis and perform a detailed review of qualitative issues that may be impacted by the initiatives developed. This final analysis is crucial to achieve the desired results.

Finally, it is relevant to mention that tourism is not, nor it should be, a top strategy for economic and social development in all states and regions of Mexico. The capability to consolidate this sector as an engine for development is, in several instances, highly correlated with the existence of natural resources, cultural aspects related to its own historical background, among others. However, diversification on sources for economic and social welfare will always be healthy for any local or regional economy, since the dependability on particular sectors will be lower, and the sensitivity to disruptions in any of them will decrease. Because of this reason, current times invite to look at tourism as an economic sector capable of generating contributions on an economic and social sphere. A multicriteria analysis is expected to be developed based on the results obtained from this research. Such analysis will consider not only the dimensions defined, but also the variables and their corresponding contributions to tourism competitiveness among the states of Mexico. In the same vein, a Markov Decision Model to analyze regional projects on a dynamic basis is also being 


\section{Al Macrothink}

Business and Economic Research ISSN 2162-4860 2013, Vol. 3, No. 1

developed. The main purpose is to model the uncertainty associated with externalities that affect the tourism sector, such as natural disasters, industrial accidents, infectious diseases, epidemic phenomena and terrorist attacks, among others, and which pose major challenges to the private and public organizations related to the tourism sector in the regions affected by these phenomenon.

\section{Acknowledgements}

The authors would like to thank the Ministry of Tourism of Mexico and Mexico's Tourism Promotion Council (CPTM). Their guidance, commitment and support were crucial to achieve the desired results. Also, our deepest gratitude to the Ministries of Tourism of the Mexican states that participated actively throughout this initiative.

\section{References}

Barros, C. P. (2005). Measuring efficiency in the hotel sector. Annals of Tourism Research, 32(2), 456-477. http://dx.doi.org/10.1016/j.annals.2004.07.011.

Begg, I., (1999). Cities and Competitiveness. Urban Studies, 36(5-6), 795-809. http://dx.doi.org/10.1080/0042098993222.

Campos, M, Naranjo, E., \& Saucedo, A. (2007). La Competitividad de los Estados Mexicanos 2007. Monterrey: EGADE.

Carral, M. (2007). Segmentos y Mercados. Líderes Mexicanos - Edición Especial Turismo. Tomo CVI.

Crouch, G., \& Brent, J. R. (1999). Tourism, Competitiveness, and Societal Prosperity. Journal of Business Research, 44(3), 137-152. http://dx.doi.org/10.1016/S0148-2963(97)00196-3

Doane, D. (2005). Applied Statistics in Business and Economics. USA: Irwin.

Dwyer L., Forsyth P., \& Rao P. (2000). The price competitiveness of travel and tourism: A comparison of 19 destinations. Tourism Management, 21(1), 9-22. http://dx.doi.org/10.1016/S0261-5177(99)00081-3

Enright, M., \& Newton J. (2004). Tourism destination competitiveness: a quantitative $\begin{array}{llll}\text { approach. Tourism } & \text { Management, } & \text { 25(6), }\end{array}$ http://dx.doi.org/10.1016/j.tourman.2004.06.008.

Instituto Mexicano para la Competitividad (IMCO). (2010). Índice de Competitividad Estatal 2010. Mexico:IMCO.

International Institute for Management Development (IMD).(2010). World Competitiveness Yearbook. Switzerland: Lausane.

Gil, J. (2000). Análisis Factorial (Factorial Analysis). Mexico:Editorial La Muralla.

Granizo, Y. (1997). La técnica del análisis factorial. Mexico:Biblioteca Nueva.

Grigoroudis, E., Politis, Y., \& Siskos, Y. (2002). Satisfaction benchmarking and customer 
classification: An application to the branches of a banking organization. International Transactions in Operational Research, 599-618.http://dx.doi.org/10.1111/1475-3995.00376

Ibáñez, R., \& García, R. (2009). Análisis de la competitividad turística en México y el mundo. Turismo y Desarrollo Local. Mexico.

INEGI. (2010). Reporte de los Estados Unidos Mexicanos. D.F.: INEGI.

Johnson, D. (2000). Multivariate methods applied to data analysis. International Thomson. USA.

Jogaratnam, G., Chon, K., McCleary, K., Mena, M., \& Yoo, J. (2005). An analysis of institutional contributors to three major academic journals: 1992-2001. Tourism Management, 26(5), 641-648. http://dx.doi.org/10.1016/j.tourman.2004.04.002

Matarrita-Cascante, D. (2010). Beyond growth - Reaching tourism-led development. Annals of Tourism Research, 37(4), 1141-1163. http://dx.doi.org/10.1016/j.annals.2010.05.004

Meyer, D. (2002). Turismo y Desarrollo Sostenible. Bogotá: Universidad Externado de Colombia.

Norese, M. F., \& Toso, F. (2004). Group decision and distributed technical support. International Transactions in Operational Research, 11(4), 395-417.http://dx.doi.org/10.1111/j.1475-3995.2004.00466.x

Propin, E., \& Sánchez, A. (2007). Tipología de los destinos turísticos preferenciales en México. México:Cuadernos de Turismo.

Racherla, P., \& Hu, C. (2010). A social network perspective of tourism research collaborations. Annals of Tourism Research, 37(4), 1012-1034. http://dx.doi.org/10.1016/j.annals.2010.03.008.

Raya, J. (2004). Estadística aplicada al Turismo (Statistics applied to Tourism). España: Prentice Hall.

Reid, R. \& Bojanic, D. (2005). Hospitality Marketing Management. Fourth edition. NJ: Wiley.

Ren, C., Pritchard, A., \& Morgan, N. (2010). Constructing tourism research: A Critical Inquiry. Annals of Tourism Research, 37(4), 885-904.http://dx.doi.org/10.1016/j.annals.2009.11.006

Rita, P. (2000). Tourism in the European Union. International Journal of Contemporary Hospitality Management, 12(7), 434-436. http://dx.doi.org/10.1108/09596110010347374

Subhash, C., \& Wellington, J. (2002). Multiple objective optimization problems in statistics. International Transactions in Operational Research, 9, 415-425. http://dx.doi.org/10.1111/1475-3995.00364.

Taleghani, M. (2010). Tourism as an Economic Development Tool. Journal of American 
Science, 6(11), 412-416.

Whitman N. (1990). The Committee meeting Alternative, Using the Delphi Technique. The Journal of Nursing Administration, 20(7-8), 30-36.

World Economic Forum (WEF). (2010). Global Competitiveness Report 2010-2011. Geneva, Switzerland.

World Travel and Tourism Council. (2010). Travel and Tourism Economic Impact, Executive Summary. London, UK.

World Tourism Organization (WTO). (2006). Poverty Alleviation Through Tourism - A Compilation of Good Practices. Madrid, SPA: WTO.

Verdiell, A., Sabatini, M., Maciel, M., \& Rodriguez, R. M. (2005). A mathematical model for zoning of protected natural areas. International Transactions in Operational Research, 12(2), 203-213.http://dx.doi.org/10.1111/j.1475-3995.2005.00498.x

Viktorovna, N. (2010). Genetic algorithms for multicriteria project selection and scheduling in the tourism sector. $\mathrm{PhD}$ Thesis, Tec de Monterrey, campus Toluca.

\section{Appendix}

Appendix 1. Dimensions and variables considered for the ICTEM

\begin{tabular}{|l|l|}
\hline 1. CULTURAL HERITAGE (CH) & $\begin{array}{l}\text { 2. NATURAL RESOURCES (NR) } \\
\text { - Number of Cultural Festivals }\end{array}$ \\
$\begin{array}{l}\text { - Number of Cultural Centers } \\
\text { - Number of World Heritage Sites }\end{array}$ & - Surface of human settlements \\
- Number of Archaeological Sites & - Mational protected areas \\
- Number of tourists to Archaeological & - Number of beaches \\
$\begin{array}{l}\text { Sites } \\
\text { - Number of Historical Monuments }\end{array}$ & $\begin{array}{l}\text { - Number of hurricanes/cyclones per year } \\
\text { - Number of Cathedrals }\end{array}$ \\
- Number of Museums & - Solid waste disposal \\
- Number of tourists to Museums & - Environmental complaints \\
- Number of firms \& organizations related & - Environmental crime rate \\
to tourism & \\
- Feature Theaters & \\
- Number of Libraries & \\
- Number of Galleries & \\
- Percentage of Indigenous Population & \\
- Presence of Indigenous Groups & \\
\hline 3. HOTEL INFRASTRUCTURE (HI) & 4. COMMUNICATIONS \\
- Density of Hotels and Motels & INFRASTRUCTURE (CI) \\
- Average number of rooms available & - National tourist arrivals \\
yearly & - International tourist arrivals \\
- Rooms for every thousand inhabitants & - Movement of persons to/from abroad \\
\hline
\end{tabular}


- Staff employed in hotels

- Hotel Occupancy Rate

- Tourist Nights in Hotels and Motels

- Average stay per tourist

- Occupancy Density at Hotels \& Motels

- Establishments with MBadge Certificates

- Number of consultants for M Badge

\section{COMPLEMENTARY SERVICES (CS)}

- Density of Restaurants

- Density of Nightclubs and Bars

- Number of people employed in

Restaurants and Bars

- Establishments with H Badge Certificates

- Certified Instructors for the H Badge

- Car Rental Companies

- Hospital Bed Density

- ATM Density

- Mobile Phone Penetration

- Parks and Recreation, Electronic Gaming Houses

- Casinos, Lotteries \& Gambling

- Sport Clubs, Spas and Similar

\section{TOURISM PROMOTION (TP)}

- Federal Resources allocated to Tourism Development

- Resources allocated for Natural Tourism Development

- Resources allocated to Cultural Tourism Development

- Resources Allocated to the State through FONATUR

- Space assigned in the "Tianguis Turístico" Fair

- Languages available in the official website

- Position finder - Website SECTUR

- Global Ranking - Website SECTUR

- Proportion of Foreign Tourists to the web site

9. ECONOMIC EFFICIENCY (EE)

- Tourism Income as a Percentage of Gross Domestic Product
- Density airports

- Communications infrastructure annual report

- Existing Leisure Areas

- Road and highway density

- Percentage of four-lane highways

- Authorized vehicle park

- Railway density

\section{PUBLIC SECURITY (PS)}

- Perception of Insecurity

- Crime rate

- Households with at least one victim

- Violence index

- Homicide index

- Crimes of banking institutions

- Crimes against public health

- Percentage of unreported crimes

- Criminal investigation unreported

- Black figure Index

- FASP Resources per Capita

- SUBSEMUN Resources per Capita

\section{GOVERNMENTAL PARTICIPATION} (GP)

- Expendit. on Tourism as a Percentage of total budget

- Income tax revenue per capita

- Revenue per capita VAT

- Expenditures by public works and social participation

- Profitability control

- Transparency index - Tax information

- Index of corruption and good governance

- Days required to set up a new business

- Days required to register property

- Days required to obtain a building permit

- Cost of enforcing contracts

10. HUMAN RESOURCES (HR)

- Available workforce

- Population employed in tourism 
- Tourism Gross Domestic Product per Capita

- Level of Private Investment in Tourism

- Importance of State's Investment in National invest.

- Percentage of Companies with Foreign Investment

- Foreign Direct Investment per capita

- National Rate of Foreign Direct Investment

- Median Income Quote

- Unemployment Rate

- Food Poverty Rate

- Strike Calls

- Crime Cates in Intellectual/Industrial Property
- Weekly average income

- Primary education rate

- Rate of secondary education

- Average Schooling level

- Number of universities in the state

- Tourism-related colleges

- College students in tourism

- Available university degrees

tourism-related

- Language schools

\section{Copyright Disclaimer}

Copyright reserved by the author(s).

This article is an open-access article distributed under the terms and conditions of the CreativeCommons Attribution license (http://creativecommons.org/licenses/by/3.0/). 